\title{
Larvicidal activity of Zanthoxylum acanthopodium essential oil against the malaria mosquitoes, Anopheles anthropophagus and Anopheles sinensis
}

\author{
Qi He®i, Wenxia Wang and Liang Zhu*
}

\begin{abstract}
Background: Zanthoxylum acanthopodium has insecticidal effect in Chinese traditional medicine. In this study, the essential oil from the dried Zanthoxy/um plant was used as a larvicidal compound against the malaria mosquitoes, Anopheles anthropophagus and Anopheles sinensis.

Methods: Compounds in the Zanthoxylum essential oil were investigated by gas chromatography and mass spectroscopy (GC-MS). The larvicidal bioassays of the whole oil, as well as the main compounds in the oil (estragole and eucalyptol) were performed using WHO method.

Results: In total, 63 main compounds (99.32\%) were found in the oils, including estragole (15.46\%), eucalyptol (10.94\%), $\beta$-caryophyllene (5.52\%), cis-linalool oxide (3.76\%), cis-limonene oxide (3.06\%). A dose-dependent effect on mortality was recorded with increasing concentrations of essential oil and compounds increasing mortality of the larvae. Larvicidal bioassays revealed that $24 \mathrm{~h} \mathrm{LC}$ 50 of the whole essential oil was $36.00 \mathrm{mg} / \mathrm{L}$ and $\mathrm{LC}_{90}$ was $101.49 \mathrm{mg} / \mathrm{L}$ against $A n$. anthropophagus, while $L C_{50}$ was $49.02 \mathrm{mg} / \mathrm{L}$ and $L C_{90}$ was $125.18 \mathrm{mg} / \mathrm{L}$ against An. sinensis. Additionally, $24 \mathrm{~h} \mathrm{LC}_{50}$ of estragole were 38.56 and $41.67 \mathrm{mg} / \mathrm{L}$ against $A n$. anthropophagus and An. sinensis, respectively, while the related $\mathrm{LC}_{90}$ were 95.90 and $107.89 \mathrm{mg} / \mathrm{L}$. LC $\mathrm{C}_{50}$ of eucalyptol were 42.41 and $45.49 \mathrm{mg} / \mathrm{L}$ against $A n$. anthropophagus and $A$ n. sinensis, while the related $\mathrm{LC}_{90}$ were 114.45 and $124.95 \mathrm{mg} / \mathrm{L}$.
\end{abstract}

Conclusion: The essential oil of $Z$. acanthopodium and its several major compounds may have potential for use in the control of malaria mosquitoes.

Keywords: Zanthoxylum acanthopodium, Essential oil, Anopheles anthropophagus, Anopheles sinensis, Larvicidal activity

\section{Background}

Malaria, a widespread disease in tropical and subtropical regions (including much of sub-Saharan Africa, Asia, and the Americas), can cause symptoms that include fever, headache, vomiting, and even progress to coma or death [1]. As the World Health Organization (WHO) estimated, there were 216 million documented cases and more than 445,000 deaths from malaria in 2016 [2].

*Correspondence: zhuliang@scut.edu.cn

College of Light Industry and Food, South China University of Technology, Guangzhou, Guangdong Province, China
As a mosquito-borne infectious disease, malaria can be caused by a bite from an infected mosquito, which can introduce the malaria parasites into the circulatory system of the human and ultimately to the liver, where they mature and reproduce [3].

Among mosquitoes, Anopheles is the only vector of human malaria [4] and, of these, 30-40 species commonly transmit parasites of the genus Plasmodium [5]. Anopheles anthropophagus and Anopheles sinensis have been chosen as the test target mosquito species in this research, because they are rife and harmful in China. The mosquito An. sinensis is a member of the Anopheles 
hyrcanus group, distinguished from other series by the presence of pale bands (usually four) on the palpi and a tuft of dark scales on the clypeus on each side. Anopheles anthropophagus is a major vector in central China, able to spread malaria 18-20 times better than An. sinensis [6, 7]. The larvae of $A n$. anthropophagus and An. sinensis live on the surface of water. Compared to adults, the ability of larvae to escape the insecticide is limited, so the time from larvae to adult is an important period to control mosquitoes [8].

Generally, mosquito larval control is carried out by conventional synthetic insecticides, which have high efficiency and low cost. Their efficacy may decay gradually because mosquitoes develop resistance against insecticides [9]. By contrast, plant essential oils, often obtained from the plant by steam distillation or hydrodistillation, constitute a rich source of bioactive compounds [10], and have emerged as a good alternative larvicidal or adulticidal agents with fewer insect resistance problems [11]. Biodegradable and nontoxic, they can be used as an ecofriendly tool as well as an economical agent in vector control [12].

Zanthoxylum acanthopodium is a shrub or small tree in the Zanthoxylum genus of Citrus family, native to southern China, Bangladesh, Bhutan, northern India, Nepal, Laos, Burma, northern Thailand Vietnam, Indonesia, and Peninsular Malaysia. It has 5-13 alternate leaves with serrated edge (3-8 $\mathrm{cm}$ long and $1-2 \mathrm{~cm}$ wide) and axillary inflorescences with densely globose clusters of unisexual flowers [13]. Much like the closely related Zanthoxylum piperitum, it has similar tongue-numbing characteristic seed pericarps, which are often used as spices in cooking, and traditional Chinese medicine reported great effect on contraception, relieving pain and killing parasites [13]. Additionally, the hydrodistilled essential oil from Zanthoxylum acanthopodium, with many active ingredients, is a novel agent with special effect. In the present study, the chemical composition of the essential oil from Zanthoxylum acanthopodium was determined and its larvicidal activity was evaluated against An. anthropophagus and An. sinensis.

\section{Methods}

\section{Plant material}

The aerial parts of Zanthoxylum acanthopodium were collected from 33 families of plants in the Ailao Mountains, Yunnan Province, China, in May 2013. Plant specimens were identified by Dr. Yin-zhang Zhou. The plants were dried under shade (at room temperature). The voucher specimen (No. IBSC/0387990) was deposited in the South China Botanical Garden, Chinese Academy of Sciences.

\section{Isolation of the essential oil}

The air-dried plant materials $(2000 \mathrm{~g})$ of Zanthoxylum acanthopodium were chopped and subjected to hydrodistillation for $6 \mathrm{~h}$ using a Clevenger type apparatus. The obtained oils were dried over hydrous sodium sulfate for $24 \mathrm{~h}$, filtered, and then stored at $4{ }^{\circ} \mathrm{C}$ in brown sealed glass vials until tested.

\section{GC analysis}

An Agilent HP-6890 gas chromatograph (Agilent Technologies, Palo Alto, CA, USA) with a HP-5 5\% phenylmethylsiloxane capillary column $(30 \mathrm{~m} \times 0.25 \mathrm{~mm}$ i.d., $0.25 \mu \mathrm{m}$ film thickness) and an FID detector was used for GC-FID analysis. Helium gas $(1 \mathrm{~mL} / \mathrm{min})$ was used as the carrier gas. Injector and mass transfer line temperatures were set at 250 and $280^{\circ} \mathrm{C}$, respectively. The EO solution $(1 \mu \mathrm{L})$ in hexane was injected and analysed under the following column conditions: initial column temperature of $40{ }^{\circ} \mathrm{C}$ for $1 \mathrm{~min}$, increased to $250{ }^{\circ} \mathrm{C}$ at a $3{ }^{\circ} \mathrm{C} / \mathrm{min}$, and maintained at $250^{\circ} \mathrm{C}$ for $20 \mathrm{~min}$.

\section{GC-MS analysis}

The oils were quantitatively and qualitatively analysed using a GC-MS 6890-5975 system (Agilent Technologies, Palo Alto, CA, USA) equipped with a HP-5 MS fused silica capillary column $(30 \mathrm{~m} \times 0.25 \mathrm{~mm}$ i.d., $0.25 \mu \mathrm{m}$ film thickness). For GC-MS detection, an electron ionization system with ionization energy of $70 \mathrm{eV}$ was used. Helium gas $(1 \mathrm{~mL} / \mathrm{min})$ was used as carrier gas. Injector and mass transfer line temperatures were set at 250 and $280{ }^{\circ} \mathrm{C}$, respectively. EO solution $(1 \mu \mathrm{L})$ in hexane was injected and analysed under the following column conditions: initial column temperature at $40{ }^{\circ} \mathrm{C}$ for $1 \mathrm{~min}$, increased to $250{ }^{\circ} \mathrm{C}$ at a $3{ }^{\circ} \mathrm{C} / \mathrm{min}$ heating ramp, and maintained at $250{ }^{\circ} \mathrm{C}$ for $20 \mathrm{~min}$. Kovats indices were calculated for all of the volatile components by using a homologous series of $n$-alkanes $\left(\mathrm{C}_{8}-\mathrm{C}_{25}\right)$ in an HP-5 MS column. The major oil components were identified by co-injection with standards (whenever possible) and confirmed using the Wiley (V.7.0) and National Institute of Standards and Technology V.2.0 GC-MS library on the basis of Kovats indices. The relative concentration of each compound in the oil was quantified on the basis of the peak area integrated in the analysis program.

\section{Mosquito larvicidal assay}

The eggs of An. sinensis and An. anthropophagus were received from Centre for Disease Control and Prevention of Guangdong Province, China. Twenty-five larvae were reared in $250 \mathrm{~mL}$ glass beaker and fed with Brewer's yeast/dog biscuit $(1: 3)[14,15]$. The beaker with larvae were maintained at $27 \pm 2{ }^{\circ} \mathrm{C}, 75 \pm 2 \%$ relative humidity 
and photoperiod of 14:10 (L:D) h. Larvicidal activity of the essential oil and of the main compounds (estragole and eucalyptol) isolated from the essential oil of Zanthoxylum acanthopodium were evaluated according to the standard procedures suggested by the WHO [16]. The essential oil and compounds were dissolved in $1 \mathrm{~mL}$ of DMSO solution and prepared into different concentrations (25, 50, 75, 100 125, and $150 \mathrm{ppm})$ using distilled water. For comparison commercial larvicide Pylarvex (Pyrethrum Board of Kenya) was used as a positive control. Twenty larvae of early fourth-instar stage were used in the larvicidal assay and five replicates were maintained for each concentration. During this experiment no food was offered to the larvae. The larval mortality was calculated after the $24 \mathrm{~h}$ exposure period.

\section{Statistical analysis}

The average larval mortality data were subjected to probit analysis for calculating $\mathrm{LC}_{50}, \mathrm{LC}_{90}$ and other statistics at $95 \%$ fiducial limits of upper confidence limit and lower confidence limit, and Chi square values were calculated by using the software using Statistical Package of Social Sciences (SPSS) 13.0 for windows, the significance level was set at $\mathrm{P}<0.05$.

\section{Results and discussion}

\section{Chemical composition of the essential oil}

The steam distillation of $2000 \mathrm{~g}$ of dried plant material yielded $7.2 \mathrm{~mL}(0.36 \%, \mathrm{v} / \mathrm{w})$ of a light- yellow oil with a distinct smell. The GC-MS analysis of Zanthoxylum acanthopodium essential oil revealed 63 components representing $99.32 \%$ of the oil (Table 1). The composition was $13.98 \%$ monoterpene hydrocarbon fraction, $24.24 \%$ oxygenated monoterpene fraction, $16.60 \%$ sesquiterpene hydrocarbon fraction, $13.75 \%$ oxygenated sesquiterpenoid fraction, $21.57 \%$ phenylpropanoids and $9.18 \%$ others. The main components of the oil were estragole (15.46\%), eucalyptol (10.94\%), $\beta$-caryophyllene (5.52\%), cis-linalool oxide (3.76\%), cis-limonene oxide (3.06\%).

In the Zanthoxylum acanthopodium essential oil, main compounds were estragole, eucalyptol and $\beta$-caryophyllene. They were often reported in the essential oil extracted from different kinds of Zanthoxylum plants. Estragole is a component isolated from various trees and plants and its extraction from Zanthoxylum plants has been described but is relatively rare. Wang et al. [17] showed that in the essential oil of fresh fruits of Zanthoxylum schinifolium, estragole was the major compound (69.52\%). Eucalyptol was common in many plants including Zanthoxylum plants in related literature. Liu et al. [18] showed that the essential oil of Zanthoxylum avicennae leaves and stems had high content of monoterpenoids including 53.05\% eucalyptol. Prieto
Table 1 Chemical composition of essential oil of Zanthoxylum acanthopodium

\begin{tabular}{|c|c|c|c|c|}
\hline Peak no. & $\mathrm{RI}^{\mathrm{a}}$ & Components & $\% \mathrm{RA}^{\mathbf{b}}$ & $\begin{array}{l}\text { Identification } \\
\text { methods }\end{array}$ \\
\hline & & Monoterpene hydrocarbons & 13.98 & \\
\hline 1 & 930 & a-Thujene & 0.62 & $M S, R I$ \\
\hline 2 & 936 & a-Pinene & 1.28 & $M S, R I$ \\
\hline 3 & 973 & Sabinene & 2.63 & $M S, R I$ \\
\hline 4 & 986 & $\beta$-Myrcene & 0.41 & $M S, R I$ \\
\hline 5 & 1012 & 3-Carene & 2.76 & $M S, R I$ \\
\hline 6 & 1024 & $\beta$-Phellandrene & 1.36 & $M S, R I$ \\
\hline 7 & 1030 & Limonene & 2.47 & $M S, R I$ \\
\hline 8 & 1040 & (Z)- $\beta$-Ocimene & 1.22 & $M S, R I$ \\
\hline \multirow[t]{2}{*}{9} & 1059 & Y-Terpinene & 1.23 & $M S, R I$ \\
\hline & & Oxygenated monoterpenes & 24.24 & \\
\hline 10 & 1036 & Eucalyptol & 10.94 & MS, RI, Co \\
\hline 11 & 1078 & cis-Linalool oxide & 3.76 & $M S, R I$ \\
\hline 12 & 1099 & Linalool & 5.10 & MS, RI, Co \\
\hline 13 & 1120 & $\begin{array}{l}\text { cis-4-Isopropyl-1-methyl- } \\
\text { 2-cyclohexen-1-ol }\end{array}$ & 0.25 & $M S, R I$ \\
\hline 14 & 1143 & Camphor $\mathrm{C} 10 \mathrm{H} 16 \mathrm{O}$ & 1.91 & $\mathrm{MS}, \mathrm{RI}$ \\
\hline 15 & 1196 & Citronellol & 0.60 & $M S, R I$ \\
\hline 16 & 1255 & Piperitone & 0.28 & $M S, R I$ \\
\hline 17 & 1257 & Geraniol & 0.73 & $M S, R I$ \\
\hline \multirow[t]{2}{*}{18} & 1270 & Perillaaldehyde & 0.67 & $M S, R I$ \\
\hline & & Sesquiterpene hydrocarbons & 16.60 & \\
\hline 19 & 1335 & $\delta$-Elemene & 0.79 & $M S, R I$ \\
\hline 20 & 1351 & a-Cubebene & 0.28 & $M S, R I$ \\
\hline 21 & 1375 & Isoledene & 0.46 & $M S, R I$ \\
\hline 22 & 1384 & $\beta$-Bourbonene & 0.92 & $M S, R I$ \\
\hline 23 & 1388 & $\beta$-Cubebene & 0.63 & $M S, R I$ \\
\hline 24 & 1390 & $\beta$-Elemene & 0.47 & $M S, R I$ \\
\hline 25 & 1418 & $\beta$-Caryophyllene & 5.52 & MS, RI, Co \\
\hline 26 & 1431 & 2-Norpinene & 0.66 & $\mathrm{MS}, \mathrm{Rl}$ \\
\hline 27 & 1438 & E-a-Bergamotene & 0.67 & $M S, R I$ \\
\hline 28 & 1458 & Seychellene & 0.28 & $M S, R I$ \\
\hline 29 & 1458 & (E)-b-Farnesene & 0.38 & $M S, R I$ \\
\hline 30 & 1474 & Y-Muurolene & 0.40 & $M S, R I$ \\
\hline 31 & 1486 & Germacrene D & 2.81 & $M S, R I$ \\
\hline 32 & 1493 & Zingiberenol & 0.63 & $M S, R I$ \\
\hline 33 & 1498 & Bicyclogermacrene & 0.34 & $\mathrm{MS}, \mathrm{Rl}$ \\
\hline 34 & 1514 & trans- $\gamma$-cadinene & 0.73 & $M S, R I$ \\
\hline \multirow[t]{2}{*}{35} & 1525 & $\beta$-Sesquiphellandrene & 0.63 & $M S, R I$ \\
\hline & & Oxygenated sesquiterpenes & 13.75 & \\
\hline 36 & 1130 & cis-Limonene oxide & 3.06 & $M S, R I$ \\
\hline 37 & 1549 & Elemol & 1.65 & $M S, R I$ \\
\hline 38 & 1562 & (trans)-Nerolidol & 0.19 & $M S, R I$ \\
\hline 39 & 1575 & Spathulenol & 1.33 & $M S, R I$ \\
\hline 40 & 1578 & Caryophyllene oxide & 2.27 & $M S, R I$ \\
\hline 41 & 1587 & Viridiflorol & 0.83 & $M S, R I$ \\
\hline 42 & 1606 & a-Humulene epoxide II & 0.75 & MS, Rl, Co \\
\hline 43 & 1639 & Isospathulenol & 0.56 & MS, RI, Co \\
\hline
\end{tabular}


Table 1 (continued)

\begin{tabular}{lllcl}
\hline Peak no. & RI $^{\mathbf{a}}$ & Components & \%RA $^{\mathbf{b}}$ & $\begin{array}{l}\text { Identification } \\
\text { methods }\end{array}$ \\
\hline 44 & 1648 & B-Eudesmol & 2.46 & $\mathrm{MS}, \mathrm{Rl}$ \\
45 & 1654 & a-Eudesmol & 0.27 & $\mathrm{MS}, \mathrm{Rl}$ \\
46 & 1666 & Bulnesol & 0.38 & $\mathrm{MS}, \mathrm{Rl}$ \\
& & Phenylpropanoids & 21.57 & \\
47 & 1045 & Benzene acetaldehyde & 0.85 & $\mathrm{MS}, \mathrm{Rl}$ \\
48 & 1229 & Estragole & 15.46 & $\mathrm{MS}, \mathrm{Rl}, \mathrm{Co}$ \\
49 & 1286 & Bornyl ester & 0.7 & $\mathrm{MS}, \mathrm{Rl}$ \\
50 & 1308 & Carvacrol & 0.68 & $\mathrm{MS}, \mathrm{Rl}$ \\
51 & 1315 & 2-Methoxy-4-vinylphenol & 0.32 & $\mathrm{MS}, \mathrm{Rl}$ \\
52 & 1357 & Eugenol & 1.32 & $\mathrm{MS}, \mathrm{Rl}$ \\
53 & 1408 & Methyl eugenol & 0.61 & $\mathrm{MS}, \mathrm{Rl}$ \\
54 & 1534 & a-Calacorene & 0.38 & $\mathrm{MS}, \mathrm{Rl}$ \\
55 & 1620 & Dill apiole & 1.25 & $\mathrm{MS}, \mathrm{Rl}$ \\
& & Others & 9.18 & \\
56 & 852 & trans-2-Hexenal & 2.73 & $\mathrm{MS}, \mathrm{Rl}$ \\
57 & 982 & 1-Octen-3-ol & 1.24 & $\mathrm{MS}, \mathrm{Rl}$ \\
58 & 1062 & trans-2-Octenal & 0.48 & $\mathrm{MS}, \mathrm{Rl}$ \\
59 & 1368 & a-Terpinyl acetate & 0.57 & $\mathrm{MS}, \mathrm{Rl}$ \\
60 & 1385 & Geranyl acetate & 1.34 & $\mathrm{MS}, \mathrm{Rl}$ \\
61 & 1396 & cis-Jasmone & 0.85 & $\mathrm{MS}, \mathrm{Rl}$ \\
62 & 1702 & 2-Hexadecanol & 1.34 & $\mathrm{MS}, \mathrm{Rl}$ \\
63 & 1971 & n-Hexadecanoic acid & 0.63 & $\mathrm{MS}, \mathrm{Rl}$ \\
& & Total identified (\%) & 99.32 & \\
\hline
\end{tabular}

$R /$ retention index, MS mass spectrum, Co co-injection with authentic compound

a Retention index relative to $n$-alkanes on HP-5 MS capillary column

b Relative area (peak area relative to the total peak area)

et al. [19] determined the major constituents of Zanthoxylum monophyllum oil were eucalyptol (9.19\%); Eiter et al. [20] analysed the essential oil from Zanthoxylum clava-herculis and found the content of eucalyptol ranged from 16 to $43 \%$. Similar research was also carried out on the essential oil from the fruits of Zanthoxylum bungeanum [21]; Zanthoxylum rhetsoides and Zanthoxylum myriacanthum [22], the content of eucalyptol is $16.0 \% 15.7 \%$ and $18 \%$, respectively. $\beta$-Caryophyllene, is also a common constituent in many Zanthoxylum essential oils. It reported to be found in the essential oils of Zanthoxylum newbouldia leaves (36\%) [23]; Zanthoxylum syncarpum (9.2-9.3\%) [24]; Zanthoxylum acanthopodium leaves (3.0\%) [25]; Zanthoxylum rubescens leaf (22.1\%) [26]; Zanthoxylum setulosum (13.7\%) [27]; Zanthoxylum ekmanii (11.5\%) [28]; Zanthoxylum procerum leaves (7.0\%) [29]. The results indicate that the $Z$. acanthopodium essential oil shares some similar main constituents with other species of Zanthoxylum.

\section{Larvicidal assays}

Tables 2, 3 displays the results on percent mortality of larvae of An. sinensis and An. anthropophagus with increase in essential oil and test compounds concentration. The mortality of An. sinensis was 17, 54, 68, 83, 94 and $100 \%$ when the oil at concentration of 25.0, 50.0, 100.0, 125 , and $150 \mathrm{mg} / \mathrm{L}$. The mortality of An. anthropophagus was 36, 62, 78, 90, 97 and $100 \%$ when the oil at concentration of $25.0,50.0,100.0,125$, and $150 \mathrm{mg} / \mathrm{L}$. The $\mathrm{LC}_{50}$ and $\mathrm{LC}_{90}$ values against $A n$. sinensis larvae were 49.02 and $125.18 \mathrm{mg} / \mathrm{L}$ and for $A n$. anthropophagus were 36.00 and $101.49 \mathrm{mg} / \mathrm{L}$, respectively. Between two compounds tested for $24 \mathrm{~h}$, estragole exhibited a stronger mosquito larvicidal activity than the oil with $\mathrm{LC}_{50} 41.67$, $38.56 \mathrm{mg} / \mathrm{L}$ and $\mathrm{LC}_{90} 107.89,95.90 \mathrm{mg} / \mathrm{L}$ for An. sinensis and $A n$. anthropophagus. Eucalyptol had less $\mathrm{LC}_{50}$ values $(45.49$ and $42.41 \mathrm{mg} / \mathrm{L})$ and $\mathrm{LC}_{90}$ values (124.95 and $111.45 \mathrm{mg} / \mathrm{L})$.

Mosquitoes, including An. sinensis and An. anthropophagus used in these experiments, act as vectors for many disease-causing viruses and cause serious health problems worldwide in both humans and animals. Although Zanthoxylum is a known potential source of anthelmintic agents for traditional Chinese medicine, only a few studies have assessed the anti-mosquito activity of Zanthoxylum species. Trongtokit et al. [30,31] showed that the essential oil from Zanthoxylum limonella had repellent effect against Aedes aegypti, Culex quinquefasciatus, and Anopheles dirus. Effects of Zanthoxylum armatum essential oil against Aedes aegypti $\left(\mathrm{LC}_{50}=54 \mathrm{ppm}\right)$, Anopheles stephensi $\left(\mathrm{LC}_{50}=58 \mathrm{ppm}\right)$ and Culex quinquefasciatus $\left(\mathrm{LC}_{50}=49 \mathrm{ppm}\right)$ was analysed by Tiwary et al. [32]. The essential oil from leaves of Zanthoxylum articulatum was examined with respect to its larvicidal properties against the larvae of Aedes aegypti and showed that $\mathrm{LC}_{50}$ was $77.62 \mathrm{ppm}$ [33]. Essential oil of Zanthoxylum piperitum had insecticidal effect against Aedes gardnerii, Anopheles barbirostris, Armigeres subalbatus, Culex tritaeniorhynchus, Culex gelidus, Culex vishnui group, and Mansonia uniformis [34]. The related activity of Zanthoxylum beecheyanum was also reported, $24 \mathrm{~h} \mathrm{LC}_{50}$ was $6.895 \mathrm{mg} /$ $\mathrm{mL}$ against Culex pipiens adults and $119.020 \mathrm{mg} / \mathrm{mL}$ against 4 instar larvae [35].

When comes to the larvicidal mechanism of the Zanthoxylum essential oil, it can be attributed to some compounds in the oil that can lead to alteration in the membrane structure of larval cells [36, 37], especially estragole, eucalyptol, $\beta$-caryophyllene and limonene, whose separated insecticidal effect have been revealed in a series of reports. Zhang et al. [38] showed estragole had strong contact toxicity against Lasioderma serricorne adults with $24 \mathrm{~h} \mathrm{LD}_{50}$ value of $15.58 \mathrm{mg} /$ adult, and in the fumigant toxicity test, the $24 \mathrm{~h} \mathrm{LD}_{50}$ was 
Table 2 Larvicidal activity of Zanthoxylum acanthopodium essential oil, estragole and eucalyptol against fourth instar Anopheles sinensis larvae

\begin{tabular}{|c|c|c|c|c|c|c|}
\hline Compounds & Concentration (mg/L) & 24 h mortality (\%) & $\mathrm{LC}_{50}(\mathrm{mg} / \mathrm{L})(95 \% \mathrm{Cl})$ & $\mathrm{LC}_{90}(\mathrm{mg} / \mathrm{L})(95 \% \mathrm{Cl})$ & Slope \pm S.E. & Chisquare (df) \\
\hline \multirow[t]{6}{*}{ Essential oil } & 25 & 17 & \multirow[t]{6}{*}{$49.02(44.15-49.41)$} & \multirow[t]{6}{*}{$125.18(105.90-141.74)$} & \multirow[t]{6}{*}{$3.29 \pm 0.28$} & \multirow[t]{6}{*}{$2.835(3)^{\mathrm{a}}$} \\
\hline & 50 & 54 & & & & \\
\hline & 75 & 68 & & & & \\
\hline & 100 & 83 & & & & \\
\hline & 125 & 94 & & & & \\
\hline & 150 & 100 & & & & \\
\hline \multirow[t]{6}{*}{ Estragole } & 25 & 28 & \multirow[t]{6}{*}{$41.67(29.48-52.07)$} & \multirow[t]{6}{*}{107.89 (82.90-178.83) } & \multirow[t]{6}{*}{$3.10 \pm 0.28$} & \multirow[t]{6}{*}{$5.994(3)^{\mathrm{a}}$} \\
\hline & 50 & 57 & & & & \\
\hline & 75 & 72 & & & & \\
\hline & 100 & 89 & & & & \\
\hline & 125 & 97 & & & & \\
\hline & 150 & 100 & & & & \\
\hline \multirow[t]{6}{*}{ Eucalyptol } & 25 & 26 & \multirow[t]{6}{*}{$45.49(33.24-56.33)$} & \multirow[t]{6}{*}{124.95 (94.78-213.84) } & \multirow[t]{6}{*}{$2.92 \pm 0.27$} & \multirow[t]{7}{*}{$5.329(3)^{\mathrm{a}}$} \\
\hline & 50 & 51 & & & & \\
\hline & 75 & 69 & & & & \\
\hline & 100 & 83 & & & & \\
\hline & 125 & 95 & & & & \\
\hline & 150 & 100 & & & & \\
\hline DMSO & & $1 \pm 0.45$ & & & & \\
\hline
\end{tabular}

Each datum represents the mean of five replicates, each set up with 20 individuals $(n=100)$

LC values are considered significantly different when $95 \% \mathrm{CI}$ fail to overlap

95\% Cl confidence interval at 95\% confidence level

a The significance level is more than 0.05 . A heterogeneity factor is used in the calculation of confidence limits

Table 3 Larvicidal activity of Zanthoxylum acanthopodium essential oil, estragole and eucalyptol against fourth instar Anopheles anthropophagus larvae

\begin{tabular}{|c|c|c|c|c|c|c|}
\hline Compounds & Concentration (mg/L) & 24 h mortality (\%) & $\mathrm{LC}_{50}(\mathrm{mg} / \mathrm{L})(95 \% \mathrm{Cl})$ & $\mathrm{LC}_{90}(\mathrm{mg} / \mathrm{L})(95 \% \mathrm{Cl})$ & Slope \pm S.E. & Chisquare (df) \\
\hline \multirow[t]{6}{*}{ Essential oil } & 25 & 36 & \multirow[t]{6}{*}{$36.00(30.90-40.61)$} & \multirow[t]{6}{*}{$101.49(88.49-121.70)$} & \multirow[t]{6}{*}{$2.85 \pm 0.27$} & \multirow[t]{6}{*}{$3.885^{\mathrm{a}}$} \\
\hline & 50 & 62 & & & & \\
\hline & 75 & 78 & & & & \\
\hline & 100 & 90 & & & & \\
\hline & 125 & 97 & & & & \\
\hline & 150 & 100 & & & & \\
\hline \multirow[t]{6}{*}{ Estragole } & 25 & 31 & \multirow[t]{6}{*}{38.56 (26.73-48.40) } & \multirow[t]{6}{*}{$95.90(74.43-153.82)$} & \multirow[t]{6}{*}{$3.24 \pm 0.29$} & \multirow[t]{6}{*}{$6.248(3)^{\mathrm{a}}$} \\
\hline & 50 & 60 & & & & \\
\hline & 75 & 78 & & & & \\
\hline & 100 & 91 & & & & \\
\hline & 125 & 99 & & & & \\
\hline & 150 & 100 & & & & \\
\hline \multirow[t]{6}{*}{ Eucalyptol } & 25 & 28 & \multirow[t]{6}{*}{$42.41(37.49-47.01)$} & \multirow[t]{6}{*}{$111.45(97.62-132.64)$} & \multirow[t]{6}{*}{$3.05 \pm 0.27$} & \multirow[t]{7}{*}{$4.749(3)^{\mathrm{a}}$} \\
\hline & 50 & 54 & & & & \\
\hline & 75 & 73 & & & & \\
\hline & 100 & 88 & & & & \\
\hline & 125 & 96 & & & & \\
\hline & 150 & 100 & & & & \\
\hline DMSO & & $2 \pm 0.55$ & & & & \\
\hline
\end{tabular}

LC values are considered significantly different when $95 \%$ CL fail to overlap

95\% Cl confidence interval at $95 \%$ confidence level

a The significance level is more than 0.05 , a heterogeneity factor is used in the calculation of confidence limits 
$5.18 \mathrm{mg} / \mathrm{L}$ air. When against Maize weevils, $24 \mathrm{~h} \mathrm{LC}_{50}$ values of estragole was $14.10 \mathrm{ppm}$ [39]. Kimbaris et al. [40] showed that $24 \mathrm{~h} \mathrm{LC}_{50}$ of eucalyptol was inactive at concentrations even as high as $100 \mathrm{mg} / \mathrm{L}$ against early fourth instar mosquito larvae of Culex pipiens. Against the 3rd instars of the Culex pipiens $24 \mathrm{~h} \mathrm{LC}_{50}$ values of eucalyptol was $91.45 \mathrm{mg} / \mathrm{L}$ [41]. The current study proved that estragole and eucalyptol played important role as insecticidal compounds in Zanthoxylum acanthopodium essential oil against two anopheline mosquito species. Yang et al. [42] showed that eugenol was the most significant compounds of Clove Bud oils with reference to repellent activity against the bean bugs Riptortus clavatus. You et al. [43] showed that $\beta$-caryophyllene, exhibited strong insecticidal and repellent activities against Lasioderma serricorne. Wang et al. [39] showed the limonene $\mathrm{LC}_{50}=6.21 \mathrm{mg} / \mathrm{L}$ for Tribolium castaneum and $14.07 \mathrm{mg} / \mathrm{L}$ air for $L$. serricorne.

To sum up, a series of investigations for chemical compounds from natural products have revealed that some essential oil with adequate active ingredients is essential to the development of new insecticidal drugs, especially in view of the vast worldwide flora. There is also some evidence indicating that essential oils often prove to be more effective than their components, indicating synergy [44].

\section{Conclusion}

In total, 63 main compounds (99.32\%) were found in Zanthoxylum acanthopodium essential oil, including estragole (15.46\%), eucalyptol (10.94\%), $\beta$-caryophyllene (5.52\%), cis-linalool oxide (3.76\%), cis-limonene oxide (3.06\%). Both whole essential oil and its main compounds (estragole and eucalyptol) showed significant larvicidal activity. The results revealed that Zanthoxylum acanthopodium essential oil could be further developed as a potential agent to control the larvae of malaria mosquito.

\section{Authors' contributions}

$\mathrm{LZ}$ designed the study and participated in the manuscript drafting. QH and WXW were responsible for laboratory examinations and data analyses. All authors read and approved the final manuscript.

\section{Acknowledgements}

The authors are grateful for financially supported by the National Natural Science Foundation of China (20676041).

\section{Competing interests}

The authors declare that they have no competing interests.

\section{Availability of data and materials}

All data and material were available in this study.

\section{Consent for publication}

The study was agreed to be published in this journal.
Ethics approval and consent to participate No applicable.

\section{Funding}

The study was financially supported by the National Natural Science Foundation of China (20676041).

\section{Publisher's Note}

Springer Nature remains neutral with regard to jurisdictional claims in published maps and institutional affiliations.

Received: 28 September 2017 Accepted: 7 May 2018

Published online: 15 May 2018

\section{References}

1. Sachs J, Malaney P. The economic and social burden of malaria. Nature. 2002;415:680-5.

2. WHO. World malaria report 2017. Geneva: World Health Organization; 2017.

3. Miller LH, Baruch DI, Marsh K. The pathogenic basis of malaria. Nature. 2002;415:673-9.

4. Steven L. Anopheles mosquito transmission of brain tumor. Med Hypotheses. 2010;74:167-8.

5. Holt RA, Subramanian GM, Halpern A. Sutton GG. The genome sequence of the malaria mosquito Anopheles gambiae. Science. 2002;298:129-49.

6. Nikookar SH, Moosa-Kazemi SH, Yaghoobi-Ershadi MR, Vatandoost H, Oshaghi MA, Ataei A, et al. Fauna and larval habitat characteristics of mosquitoes in Neka County, Northern Iran. J Arthropod Borne Dis. 2015;9:253-66.

7. Gentile JE, Rund SS, Madey GR. Modelling sterile insect technique to control the population of Anopheles gambiae. Malar J. 2015;14:587.

8. Zaridah MZ, Azah MAN, Rohani A. Mosquitocidal activities of Malaysian plants. J Trop Forest Sci. 2006;18:74-80.

9. Weber DJ, Rutala WA. Use of germicides in the home and the healthcare setting: Is there a relationship between germicide use and antibiotic resistance? Infect Control Hosp Epidemiol. 2006;27:1107-19.

10. Anthony JP, Fyfe L, Smith H. Plant active components a resource for antiparasitic agents? Trends Parasitol. 2005;21:462-8.

11. Asase A, Oteng-Yeboah AA, Odamtten GT, Simmonds MSJ. Ethnobotanical study of some Ghanaian anti-malarial plants. J Ethnopharmacol. 2005;99:273-9.

12. Wongsrichanalai $C$, Pickard AL, Wernsdorfer WH. Epidemiology of drugresistant malaria. Lancet Infect Dis. 2002;2:209-18.

13. Rana VS, Blazquez MA. Terpenoid constituents of Zanthoxylum acanthopodium DC. Leaves. J Essent Oil Res. 2008;20:515-6.

14. Zhu L, Tian Y. Chemical composition and larvicidal activity of essential oil of Artemisia gilvescens against Anopheles anthropophagus. Parasitol Res. 2013;112:1137-42.

15. Cheng SS, Liu JY, Tsai KH, Chen WJ, Chang ST. Chemical composition and mosquito larvicidal activity of essential oils from leaves of different Cinnamomum osmophloeum provenances. J Agric Food Chem. 2004:52:4385-400.

16. WHO. Instruction for determining the susceptibility or resistance of mosquito larvae to insecticides. Geneva: World Health Organization; 1981

17. Wang CF, Yang K, Zhang HM, Cao J, Fang R, Liu ZL, et al. Components and insecticidal activity against the maize Weevils of Zanthoxylum schinifolium fruits and leaves. Molecules. 2011:16:3077-88.

18. Liu XC, Liu QY, Zhou LG, Liu QR, Liu ZL. Chemical composition of Zanthoxylum avicennae essential oil and its larvicidal activity on Aedes albopictus Skuse. Trop J Pharm Res. 2014;13:399-404.

19. Prieto JA, Patino OJ, Delgado WA, Moreno JP, Cuca LE. Chemical composition, insecticidal and antifungal activities of fruit essential oils of three Colombian Zanthoxylum species. Chilean J Agric Res. 2011;71:73-82. 
20. Eiter LC, Fadamiro H, Setzer WN. Seasonal variation in the leaf essential oil composition of Zanthoxylum clava-herculis growing in Huntsville, Leaves, Alabama. Nat Prod Commun. 2010;5:457-60.

21. Gong YW, Huang YF, Zhou LG, Shi XY, Guo ZJ, Wang MG, Jiang WB. Chemical composition and antifungal activity of the fruit oil of Zanthoxylum bungeanum Maxim. (Rutaceae) from China. J Essent Oil Res. 2009;21:174-8.

22. Weyerstahl P, Marschall H, Splittgerber U, Son PT, Giang PM, Kaul VK. Constituents of the essential oil from the fruits of Zanthoxylum rhetsoides Drake from Vietnam and from the aerial parts of Zanthoxylum alatum Roxb. from India. Flavour. Fragrance J. 1999;14:225-9.

23. Olounlade PA, Azando EVB, Hounzangbe-Adote MS, Ha TBT, Leroy E, Moulis $C$, et al. In vitro anthelmintic activity of the essential oils of Zanthoxylum zanthoxyloides and Newbouldia laevis against Strongyloides ratti. Parasitol Res. 2012;110:1427-33.

24. Vieira MGS, de Freitas JVB, Neto MND, Gramosa NV, Nunes EP. Volatile chemical constituents of the leaves and twigs from Zanthoxylum syncarpum. Tull Quimica Nova. 2009;32:391-3.

25. Rana VS, Blazquez MA. Volatile constituents of the seed coat of Zanthoxylum rhetsa (Roxb.) DC. J Essent Oil Res. 2010;22:430-2.

26. Oyedeji AO, Lawal OA, Adeniyi BA, Alaka SA, Tetede E. Essential oil composition of three Zanthoxylum species. J Essent Oil Res. 2008;20:69-71.

27. Boehme AK, Noletto JA, Haber WA. Setzer WN. Bioactivity and chemical composition of the leaf essential oils of Zanthoxylum rhoifolium and Zanthoxylum setulosum from Monteverde, Costa Rica. Nat Prod Res. 2008;22:31-6.

28. Facundo VA, Rezende CM, Pinto AC, de Morais SM. Essential oil of Zanthoxylum ekmanii (Urb.) Alain leaves. J Essent Oil Res. 2003;15:402-3.

29. Vila R, Iglesias J, Canigueral S, Ciccio JF. Composition of the essential oil from leaves of Zanthoxylum procerum from Costa Rica. J Essent Oil Res. 2002;14:44-6.

30. Trongtokit Y, Rongsriyam Y, Komalamisra N, Apiwathnasorn C. Comparative repellency of 38 essential oils against mosquito bites. Phytother Res. 2005;19:303-9.

31. Trongtokit $Y$, Rongsriyam $Y$, Komalamisra N, Krisadaphong P, Apiwathnasorn C. Laboratory and field trial of developing medicinal local Thai plant products against four species of mosquito vectors. Southeast Asian J Trop Med Public Health. 2004;35:325-33.

32. Tiwary M, Naik SN, Tewary DK, Mittal PK, Yadav S. Chemical composition and larvicidal activities of the essential oil of Zanthoxylum armatum DC (Rutaceae) against three mosquito vectors. J Vector Dis. 2007;44:198-204.

33. Feitosa EMA, Arriaga AMC, Lemos TLG, Lima JQ, Vasconcelos JNE, Oliveira MCF, et al. Zanthoxylum artkulatum engler (Rutaceae) essential oil: chemical composition and larvicidal activity. J Essent Oil Res. 2007;19:384-6.
34. Kamsuk K, Choochote W, Chaithong U, Jitpakdi A, Tippawangkosol P, Riyong DY, et al. Effectiveness of Zanthoxylum piperitum-derived essential oil as an alternative repellent under laboratory and field applications. Parasitol Res. 2007;100:339-45.

35. Peng YH, Zhang Y, Zeng DQ, Chen FF, Zhong HY, Li ZH, Huang Y. Bioactivity and chemical composition of essential oil from Zanthoxylum beecheyanum var. alatum leaves against Culex pipiens quinquefasciatus (Diptera: Culicidae). Chin J Appl Ecol. 2009;20:1488-94.

36. Eneh LK, Saijo H, Borg-Karlson AK, Lindh JM, Rajarao GK. Cedrol, a malaria mosquito oviposition attractant is produced by fungi isolated from rhizomes of the grass Cyperus rotundus. Malar J. 2016;15:478.

37. Mavundza EJ, Maharaj R, Chukwujekwu JC, Finnie JF, Van Staden J. Screening for adulticidal activity against Anopheles arabiensis in ten plants used as mosquito repellent in South Africa. Malar J. 2014;13:173.

38. Zhang WJ, You CX, Yang K, Chen R, Wang Y, Wu Y, et al. Bioactivity of Essential Oil of Artemisia argyi Levl. et Van. and its main compounds against Lasioderma serricorne. J Oleo Sci. 2014;63:829-37.

39. Wang $Y$, You CX, Wang CF, Yang $K$, Chen $R$, Zhang WJ, et al. Chemical constituents and insecticidal activities of the essential oil from Amomum tsaoko against two stored-product insects. J Oleo Sci. 2014;63:1019-26.

40. Kimbaris AC, Koliopoulos G, Michaelakis A, Konstantopoulou MA. Bioactivity of Dianthus caryophyllus, Lepidium sativum, Pimpinella anisum, and Illicium verum essential oils and their major components against the West Nile vector Culex pipiens. Parasitol Res. 2012;111:2403-10.

41. Maghraby EIS, Nawwar GA, Reda FAB, Helmy N, Omnia MHMK. Toxicological studies for some agricultural waste extracts on mosquito larvae and experimental animals. Asian Pac J Trop Biomed. 2012;2:558-63.

42. Yang LC, Li R, Tan J, Jiang ZT. Polyphenolics composition of the leaves of Zanthoxylum bungeanum Maxim. grown in Hebei, China, and their radical scavenging activities. J Agr Food Chem. 2013;61:1772-8.

43. You CX, Wang Y, Zhang WJ, Yang K, Wu Y, Geng ZF, et al. Chemical constituents and biological activities of the Purple perilla essential oil against Lasioderma serricorne. Ind Crop Prod. 2014;61:331-7.

44. Don-Pedro KN. Investigation of single and joint fumigant insecticidal action of citrus peel oil components. Pestic Sci. 1999;46:79-84.

Ready to submit your research? Choose BMC and benefit from:

- fast, convenient online submission

- thorough peer review by experienced researchers in your field

- rapid publication on acceptance

- support for research data, including large and complex data types

- gold Open Access which fosters wider collaboration and increased citations

- maximum visibility for your research: over $100 \mathrm{M}$ website views per year

At BMC, research is always in progress.

Learn more biomedcentral.com/submissions 